\title{
KUALITAS FISIKA KIMIA SUSU SAPI DI KABUPATEN JEMBER DAN PENGEMBANGANNYA DALAM BUKU NON-TEKS
}

\author{
Kennis Rozana ${ }^{1 *}$, Dwi Wahyuni ${ }^{2}$, Mochammad lqbal ${ }^{3}$ \\ 1 Jurusan Biologi, Fakultas MIPA, Universitas Negeri Malang, Jawa Timur, Indonesia \\ 2 Program Studi Bioteknologi, Fakultas MIPA, Universitas Negeri Malang, Jawa Timur, Indonesia \\ 3 Program Studi Pendidikan Biologi, Fakultas Keguruan dan Ilmu Pendidikan, Universitas Negeri Jember, \\ Jawa Timur, Indonesia \\ *corresponding author / email : kennis.rozana.fmipa@um.ac.id
}

Penelitian ini bertujuan untuk mengetahui kualitas fisika dan kimia susu sapi yang diproduksi di Kabupaten Jember dan memberikan edukasi yang tepat bagi masyarakat terkait prosedur penilaian kelayakan susu yang akan dikonsumsi melalui buku non-teks. Analisis kualitas fisika susu sapi yang dilakukan meliputi uji didih, uji alkohol, dan uji berat jenis sedangkan analisis kualitas kimia susu sapi yang dilakukan meliputi uji pH dan uji kadar lemak. Pengembangan buku nonteks dilakukan dengan menggunakan model pengembangan R2D2 (Reflective, Recursive, Design, and Development). Berdasarkan hasil penelitian diketahui bahwa sampel susu sapi dari industri susu A dan industri susu B memiliki kualitas fisika dan kimia yang sesuai dengan standar kualitas susu yang aman untuk dikonsumsi menurut SNI dan Codex. Hasil rata-rata validasi produk buku non-teks yang dikembangkan sebesar 94.84 persen dari ketiga validator. Dengan demikian produk buku non-teks tersebut sangat layak digunakan sebagai buku non-teks, khususnya buku non-teks untuk pengayaan pengetahuan.

\section{Kata Kunci : susu, kualitas, fisika, kimia, buku non-teks}

This study aims to determine the physical and chemical quality of cow's milk produced in Jember and provide an appropriate education for the community regarding the procedure for assessing the feasibility of milk to be consumed through non-text books. The analysis of the physical quality of cow's milk includes boiling test, alcohol test, and specific gravity test, while the chemical quality analysis of cow's milk includes $\mathrm{pH}$ test and fat content test. The development of non-text books is carried out using the R2D2 (Reflective, Recursive, Design, and Development) development model. Based on the results of the study, it is known that samples of cow's milk from dairy industry A and milk industry B have physical and chemical qualities that are in accordance with milk quality standards that are safe for consumption according to SNI and Codex. The average result of the validation of non-textbook products developed was 94.84 percent from the three validators. Thus, the non-textbook product is very suitable to be used as a non-textbook, especially nontext books for knowledge enrichment.

\section{Keywords : milk, quality, physics, chemistry, non-text books}


Susu merupakan salah satu jenis minuman yang sering dikonsumsi oleh masyarakat karena kandungannya yang kaya nutrisi. Sudut pandang terkait susu sebagai minuman kesehatan ternyata tidak sepenuhnya benar. Kandungan nutrisi pada susu tidak hanya dibutuhkan oleh manusia tetapi juga oleh organisme lain seperti mikroorganisme (Abargouei et al., 2012; Abreu et al., 2012). Proses produksi dan pengolahan susu yang tidak sesuai standar akan membuat susu tidak lagi sehat untuk dikonsumsi, tetapi justru menyimpan banyak potensi penyakit membahayakan bagi masyarakat (Abreu et al., 2012; Chen et al., 2012).

Menurut Arriola et al., di seluruh dunia terdapat jutaan orang, khususnya bayi dan anak-anak menderita hingga meninggal dunia setiap tahun akibat penyakit yang ditularkan melalui beberapa produk makanan, salah satunya melalui produk susu. Setiap tahun juga terdapat sekitar 1500 juta kejadian diare pada balita dan diperkirakan $70 \%$ kasus diare tersebut terjadi karena beberapa produk makanan yang terkontaminasi. Dari sekian banyak kasus keracunan akibat mengonsumsi produk susu tersebut menunjukkan rendahnya kualitas susu yang dihasilkan oleh beberapa industri susu. Sementara itu, di Kabupaten yang memiliki beberapa industri susu belum pernah ditemukan adanya kasus keracunan susu sehingga perlu dilakukan pengujian kualitas susu yang dihasilkan oleh beberapa industri susu di Kabupaten Jember untuk mengetahui kualitas fisika dan kimia susu yang dihasilkan oleh beberapa industri susu di Kabupaten Jember.

Susu yang tidak layak konsumsi pada umumnya mengalami perubahan fisika dan kimia akibat adanya aktivitas metabolisme mikroorganisme di dalam produk susu. Perubahan kualitas fisika dan kimia susu dapat dijadikan sebagai salah satu indikator untuk mengetahui pencemaran produk susu oleh mikroorganisme. Pencemaran produk susu oleh mikroorganisme dapat menyebabkan masa simpan susu menjadi relatif singkat (Malik et al., 2012; Josse et al., 2011; Mozaffarian et al., 2011). Pengetahuan tentang pentingnya mengetahui dan menjaga kualitas susu juga harus ditanamkan pada masyarakat luas, khususnya produsen dan konsumen penikmat susu melalui suatu produk buku nonteks sebagai salah satu bahan referensi. Pemilihan pemanfaatan hasil penelitian kualitas fisika dan kimia susu ke dalam buku non-teks dikarenakan buku non-teks tidak terbatas pada jenjang pendidikan tertentu sehingga dapat digunakan oleh produsen susu, konsumen susu, atau masyarakat luas lainnya.

Pengembangan buku non-teks dilakukan dengan menggunakan model pengembangan Constructivist Instructional Design (C-ID) atau yang lebih dikenal dengan R2D2 (Reflective, Recursive, Design. And Development) yang dikembangkan oleh Willis pada tahun 1995. Pemilihan model pengembangan R2D2 dikarenakan model pengembangan yang mengacu pada pandangan konstruktivis memiliki banyak kelebihan dibandingkan dengan model pengembangan yang mengacu pada pandangan behavioristik. Model pengembangan yang mengacu pada pandangan konstruktivis lebih bersifat recursive, yakni berpijak pada masalah nyata yang bersifat kontekstual dengan proses pengembangan tidak linier, tidak berurutan, pemecahannya tidak melibatkan satu keahlian saja, dan tidak berorientasi pada pencapaian tujuan tertentu yang terikat dalam kurikulum sehingga penyusunan buku non-teks dapat menjadi lebih kreatif. Lebih kolaboratif, dan menarik tanpa harus terikat pada beberapa aturan baku seperti yang ada pada model pengembangan yang mengacu pada pandangan behavioristik (Jushadi et al., 2015). Berdasarkan beberapa dasar pemikiran di atas perlu dilakukan penelitian terkait "Kualitas Fisika dan Kimia Susu Sapi di Kabupaten Jember serta Pemanfaatannya dalam Penyusunan Buku Non-Teks"

\section{METODE}

Penelitian ini dilakukan dalam dua tahap berbeda. Tahap penelitian pertama merupakan penelitian deskriptif yang bertujuan untuk mengetahui kualitas fisika dan kimia susu sapi yang dihasilkan oleh beberapa industri susu di Kabupaten Jember. Tahap penelitian kedua merupakan penelitian pengembangan produk berupa buku non-teks yang berisi hasil dari penelitian pada tahap pertama.

Pengujian kadar lemak dan berat jenis susu dilakukan di Laboratorium Analisis Pangan Politeknik Negeri Jember. Selain dilakukan pengujian kualitas fisika dan kimia susu, juga dilakukan pengujian bakteriologis hapusan tangan pemerah, wawancara dengan produsen terkait proses produksi dan 
distribusi susu, serta pengamatan kondisi lokasi peternakan, lokasi pemerahan, dan kondisi lokasi proses produksi susu yang meliputi suhu, kelembaban, intensitas cahaya, pertukaran udara, serta sistem pembuangan air dan kotoran.

\section{Pengambilan Sampel}

Sample yang digunakan dalam penelitian ini terdiri dari dua jenis sampel susu masing-masing dari industri susu yang berbeda. Pemilihan sampel industri susu menggunakan metode Purposed Random Sampling. Sampel industri susu pertama merupakan industri susu di Garahan yang berada di bawah pengawasan Dinas Peternakan Provinsi Jawa Timur dan sampel industri susu kedua merupakan industri susu di Mangli yang berada di bawah lemaga sekolah dan dikelola oleh para siswa.

Pengambilan sampel dilakukan dengan mengambil sampel susu segar yang baru diperah sebanyak $250 \mathrm{~mL}$ dan hapusan tangan pemerah di lokasi pemerahan dengan ketentuan pengambilan sampel susu sebanyak 3 kali pengulangan (didasarkan pada teknik Simple Random Sampling karena populasi homogen) dari masing-masing industri susu, sementara untuk hapusan tangan pemerah dilakukan satu kali pada masing-masing industri susu. Sampel susu dimasukkan dalam botol steril dan dibawa di laboratorium menggunakan ice box dengan suhu 4oC untuk menjaga kualitas susu.

\section{Pengujian Kualitas Fisika Susu}

Uji Didih

Sebanyak $5 \mathrm{~mL}$ sampel susu dimasukkan ke dalam tabung reaksi dan dipanaskan dengan penjepit kayu sampai mendidih. Apabila terdapat gumpalan maka hasil uji didih dinyatakan positif, apabila tidak terdapat gumpalan maka hasil uji didih dinyatakan negatif.

\section{Uji Alkohol}

Sebanyak $5 \mathrm{~mL}$ sampel susu dan $5 \mathrm{~mL}$ alkohol 70\% dimasukkan ke dalam tabung reaksi dan divortex hingga homogen. Apabila terdapat butiran di dinding tabung reaksi maka hasil uji alkohol dinyatakan positif, apabila tidak terdapat butiran di dinding tabung reaksi maka hasil uji alkohol dinyatakan negatif.

\section{Uji Berat Jenis}

Sebanyak $100 \mathrm{~mL}$ sampel susu dimasukkan pada tabung ukur laktodensimeter kemudian ditunggu selama 1 menit. Selanjutnya hasil yang terbaca pada skala kemudian dibandingkan dengan berat jenis minimum susu yang baik yaitu $1.208 \mathrm{gram} / \mathrm{mL}$.

\section{Pengujian Sifat Kimia Susu}

\section{Uji pH Susu}

Sebanyak $100 \mathrm{~mL}$ sampel susu dimasukkan ke dalam tabung erlemeyer dan kemudian dimasukkan pH elektrik ke dalam susu selama 1 menit atau sampai nilai yang tercantum pada $\mathrm{pH}$ elektrik stabil.

\section{Uji Kadar Lemak Susu}

Sebanyak $10 \mathrm{~mL}$ asam belerang, $11 \mathrm{~mL}$ sampel susu, dan $1 \mathrm{~mL}$ amylalkohol dengan konsentrasi 91-92\% dimasukkan ke dalam butirometer. Kemudian butirometer ditutup dan divortex sampai homogen. Kemudian dipanaskan pada suhu $65-70^{\circ} \mathrm{C}$ selama 10 menit dan disentrifugasi selama 5 menit dengan kecepatan 1200 putaran permenit. Selanjutnya butirometer diletakkan lagi pada penangas air selama 5 menit dan kadar lemak dapat dilihat pada skala butirometer.

\section{Pengembangan Buku Non-Teks}

Pengembangan buku non-teks menggunakan model R2D2 umumnya terdiri dari tiga tahap yaitu: 1) Define, 2) Design, dan 3) Dissemination, akan tetapi dalam penelitian ini tahap Dissemination tidak dilakukan karena implementasi buku non-teks masih dalam tahap uji coba, yaitu suatu bentuk pengembangan untuk menguji validitas dan reliabilitas instrumen yang digunakan. Dalam tahap pemgembangan dilakukan beberapa modifikasi sebagai berikut. 


\section{Tahap Definition}

Pembentukan team partisipatory bersifat bebas berasal dari dosen, ahli gizi, rekan sejawat, produsen, distributor, dan konsumen susu yang kemudian dilakukan pemecahan masalah secara progresif dengan mengembangkan masukan dari tim pengembang dan menentukan pemecahan masalah yang paling cocok dan kontekstual terkait pengadaan buku non-teks.

\section{Tahap Design and Development}

Pemilihan materi dan dan format seleksi yang akan digunakan kemudian dilanjutkan dengan pemilihan format produk dan media hingga mendesain dan mengembangkan produk berupa buku non-teks.

Selanjutnya setelah pengembangan produk dilakukan validasi oleh beberapa ahli materi, ahli media yang terdiri dari 1 orang sebagai ahli media dan 2 orang sebagai ahli materi. Validasi buku nonteks tersebut mengacu pada Kriteria Mutu (Standar) Buku Non-Teks yang ditentukan oleh Pusat Kurikulum dan Perbukuan yang terdiri atas kelayakan isi atau materi, kelayakan penyajian, kelayakan bahasa, kelayakan kegrafikaan, dan komponen kelayakan tambahan lainnya (Rostina et al., 2016; Priansa, 2015).

\section{HASIL DAN PEMBAHASAN}

Selama pengambilan sampel juga dilakukan observasi tempat pemerahan dari masing-masing industri susu. Pada industri susu A terdapat 17 ekor sapi perah dengan jumlah sapi perah yang produktif sebanyak 13 ekor sedangkan pada industri susu B terdapat 9 ekor sapi perah dengan jumlah sapi perah yang produktif sebanyak 7 ekor. Perbedaan jumlah sapi perah yang dimiliki masing-masing industri susu dengan jumlah sapi perah yang produktif dikarenakan oleh beberapa hal, seperti sapi perah dalam keadaan tidak sehat, masih dalam keadaan laktasi, dan umur sapi perah masih terlalu muda sehingga belum mampu menghasilkan susu dengan kualitas yang baik. Hasil observasi masingmasing industri susu secara rinci dapat dilihat pada Tabel 1.

Tabel 1. Hasil observasi masing- masing sampel industri susu

\begin{tabular}{clll}
\hline \multirow{2}{*}{ No. } & \multirow{2}{*}{ Kriteria } & \multicolumn{2}{c}{ Sampel Industri Susu } \\
\cline { 3 - 4 } 1. & Pakan & Rumput kaki gajah & \multicolumn{1}{c}{ B } \\
\hline 2. & Air Cuci & Air mengalir (dari sumur) & $\begin{array}{l}\text { Ampas singkong dan } \\
\text { konsentrat }\end{array}$ \\
\hline 3. & Ventilasi & $\begin{array}{l}\text { Tempat pemerahan berupa ruang terbuka } \\
\text { dengan beberapa sekat }\end{array}$ & $\begin{array}{l}\text { Air mengalir (dari sumur) } \\
\text { ruang terbuka dengan } \\
\text { beberapa sekat }\end{array}$ \\
\hline 4. & $\begin{array}{l}\text { Tempat } \\
\text { pembuangan } \\
\text { kotoran }\end{array}$ & $\begin{array}{l}\text { Dalam tempat berupa karung (dikemas } \\
\text { sedemikian rupa untuk dijual) }\end{array}$ & $\begin{array}{l}\text { Di samping tempat } \\
\text { pemerahan (dikumpulkan } \\
\text { untuk dibuat kompos) }\end{array}$ \\
\hline 5. & $\begin{array}{l}\text { Prosedur } \\
\text { pemerahan }\end{array}$ & $\begin{array}{l}\text { Terdapat prosedur khusus seperti } \\
\text { penggunaan sepatu boots untuk pemerah, } \\
\text { mencuci tangan, memandikan sapi perah } \\
\text { sebelum diperah, dan pembersihan } \\
\text { kandang. }\end{array}$ & $\begin{array}{l}\text { Terdapat prosedur khusus } \\
\text { berupa mencuci tangan dan } \\
\text { penyiraman tempat } \\
\text { pemerahan. }\end{array}$ \\
\hline 6. & $\begin{array}{l}\text { Persyaratan Sapi } \\
\text { yang akan diperah }\end{array}$ & $\begin{array}{l}\text { Sapi mastitis, alergi, dan sapi yang } \\
\text { memiliki nafsu makan dibawah normal } \\
\text { tidak boleh diambil air susunya }\end{array}$ & $\begin{array}{l}\text { Semua sapi boleh diambil } \\
\text { susunya jika sapi sudah } \\
\text { mampu menghasilkan susu. }\end{array}$ \\
\hline
\end{tabular}

Berdasarkan hasil observasi dan wawancara di lapangan, diperoleh data bahwa sampel industri susu A memiliki kriteria persyaratan produksi susu yang lebih mendekati persyaratan produksi yang telah ditetapkan. Hal ini terlihat dari pengadaan pakan, air cuci, ventilasi, tempat pembuangan kotoran, prosedur pemerahan dan pemeliharan ternak yang lebih ketat dibandingkan pada industri susu B. Lokasi dan kondisi pemerahan dapat dilihat pada Gambar 1. 

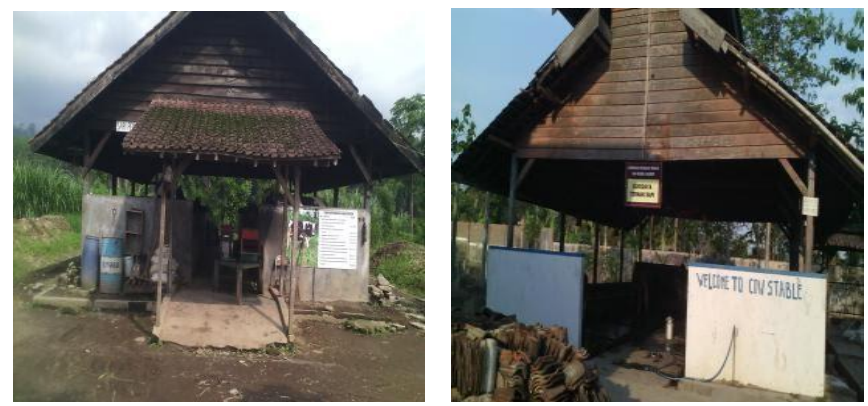

Gambar 1. Lokasi Pemerahan. Industri susu A di Garahan (kiri) dan Industri susu B di Mangli (kanan)

\section{Hasil Pengambilan Sampel Hapusan Tangan Pemerah}

Pengambilan sampel hapusan tangan pemerah dilakukan dengan tujuan untuk mengetahui kebersihan tangan pemerah dari mikroorganisme, khususnya mikroorganisme yang menjadi objek dalam penelitian ini, yaitu Escherichia coli. Pada proses pengamatan hapusan tangan pemerah diperoleh hasil yang dapat dilihat pada Tabel 2.

Tabel 2. Hasil pengamatan masing-masing sampel hapusan tangan pemerah

\begin{tabular}{clll}
\hline Sampel & \multicolumn{1}{c}{ Hasil } & \multicolumn{1}{c}{ Keterangan } \\
\hline A & $\begin{array}{l}\text { Tidak tumbuh Escherichia coli, } \\
\text { tumbuh koloni lain selain } \\
\text { Escherichia coli }\end{array}$ & $\begin{array}{l}\text { Biansperwarna ungu kehitaman dengan warna } \\
\text { transpan disekelilingnya dan biakan lain berwarna } \\
\text { kuning transparan }\end{array}$ \\
\hline B & $\begin{array}{l}\text { Tidak tumbuh Escherichia coli, } \\
\text { tumbuh koloni lain selain } \\
\text { Escherichia coli }\end{array}$ & $\begin{array}{l}\text { Biakan berwarna ungu kehitaman dengan warna } \\
\text { transparan di sekelilingnya }\end{array}$ \\
\hline
\end{tabular}

Berdasarkan Tabel 2 di atas, dapat diketahui bahwa dua sampel hapusan tangan yang diambil dari pemerah pada industri susu $A$ dan industri susu $B$ tidak menunjukkan adanya bakteri Escherichia coli, karena dalam medium EMBA tersebut tidak ditemukan adanya koloni yang berwarna hijau metalik, tetapi justru menunjukkan tumbuhnya koloni lain yang memiliki karakter biakan berwarna ungu kehitaman dengan warna transparan di sekelilingnya dan koloni lain yang memiliki karakter biakan berwarna kuning transparan.

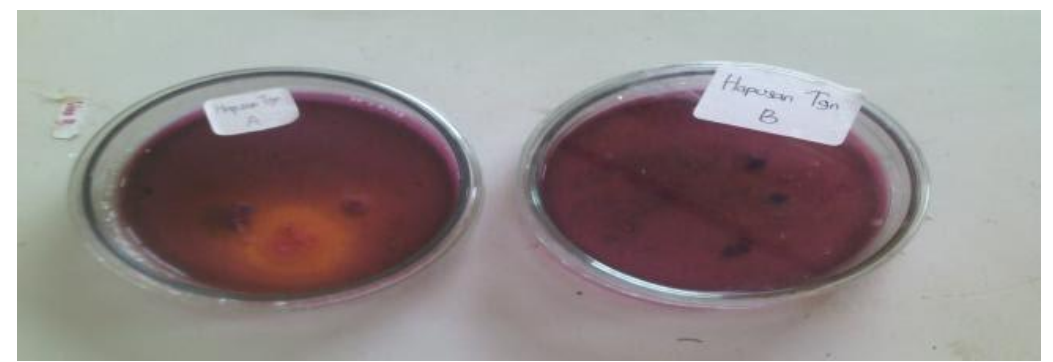

Gambar 2. Koloni yang tumbuh pada medium EMBA dari sampel hapusan tangan pemerah. Hapusan tangan A (kiri) dan hapusan tangan B (kanan)

\section{Hasil Pengujian Kualitas Susu di Laboratorium}

Pengujian sampel susu di laboratorium meliputi pengujian kualitas fisika dan kualitas kimia susu. Pada masing-masing pengujian sampel diperoleh data sebagai berikut.

\section{Hasil pengujian kualitas fisika susu}

Pengujian kualitas fisika susu yang dilakukan pada penelitian ini meliputi uji didih, uji alkohol, dan uji berat jenis. Pada masing-masing pengujian tersebut diperoleh data kualitas fisika susu sebagai berikut.

$\underline{\text { Uji Didih }}$

Uji didih dilakukan dengan tujuan untuk mengetahui susunan susu. Susu yang baik menurut SNI 
harus menunjukkan hasil negatif pada uji didih ini yang ditandai dengan tidak terdapatnya gumpalan pada susu. Hasil pengujian sampel dapat dilihat pada Tabel 3.

Tabel 3. Hasil uji didih masing-masing sampel susu

\begin{tabular}{|c|c|c|c|c|}
\hline No. & Sampel & $\begin{array}{c}\text { Positif } \\
\text { (Ada Gumpalan) }\end{array}$ & $\begin{array}{c}\text { Negatif } \\
\text { (Tidak Ada Gumpalan) }\end{array}$ & Keterangan \\
\hline 1 & A1 & & v & $\begin{array}{l}\text { Sesuai dengan persyaratan } \\
\text { kualitas susu menurut SNI }\end{array}$ \\
\hline 2 & $A 2$ & & v & $\begin{array}{l}\text { Sesuai dengan persyaratan } \\
\text { kualitas susu menurut SNI }\end{array}$ \\
\hline 3 & A3 & & $v$ & $\begin{array}{l}\text { Sesuai dengan persyaratan } \\
\text { kualitas susu menurut SNI }\end{array}$ \\
\hline 4 & B1 & & $v$ & $\begin{array}{l}\text { Sesuai dengan persyaratan } \\
\text { kualitas susu menurut SNI }\end{array}$ \\
\hline 5 & B2 & & v & $\begin{array}{l}\text { Sesuai dengan persyaratan } \\
\text { kualitas susu menurut SNI }\end{array}$ \\
\hline 6 & B3 & & V & $\begin{array}{l}\text { Sesuai dengan persyaratan } \\
\text { kualitas susu menurut SNI }\end{array}$ \\
\hline
\end{tabular}

Berdasarkan Tabel 3 di atas, dapat diketahui bahwa semua sampel susu dari industri susu A dan industry susu B menunjukkan hasil negatif pada uji didih. Alasan utama yang menyebabkan susu menunjukkan hasil positif pada uji didih adalah susu memang sudah pecah saat pemerahan, mengandung kolostrum yang strukturnya berbeda dengan struktur susu pada umumnya, sapi dalam masa kering kandang (tidak berlaktasi), dan penyakit mastitis (Sousa et al., 2012). Selain itu, faktor lain yang dapat menyebabkan susu menjadi pecah atau membentuk gumpalan pada uji didih dapat dikarenakan oleh adanya kontaminasi mikroorganisme pada saat produksi, penyimpanan, transportasi, dan distribusi susu (Sanders, 2012). Pecahnya susu menyebabkan kualitas susu menjadi rendah sehingga tidak layak untuk dikonsumsi karena ada kemungkinan bahwa kadar asam yang terkandung dalam susu cukup tinggi (Struijk et al., 2001).

Uji Alkohol

Uji alkohol pada dasarnya memiliki tujuan yang hampir sama dengan uji didih, yakni untuk mengetahui susunan susu, tetapi pada uji alkohol ini lebih ditekankan pada susunan kasein susu. Susu yang baik menurut SNI harus menunjukkan hasil negatif pada uji alkohol yang ditandai dengan tidak terdapatnya gumpalan pada susu setelah sampel ditambahkan alkohol. Hasil pengujian sampel dapat dilihat pada Tabel 4.

Berdasarkan Tabel 4. di atas, dapat diketahui bahwa sampel susu dari industri susu A dan industry susu B menunjukkan hasil negatif pada uji alcohol. Menurut Tong et al., (2011) kasein dalam susu dapat berkoagulasi oleh asam yang terbentuk dalam susu sebagai hasil dari aktivitas mikroorganisme. Kasein yang telah mengalami koagulasi apabila diendapkan oleh asam lemah akan membebaskan kalsium dan apabila diendapkan oleh alkohol akan menghasilkan kalsium kasienat yang membuat susunan susu terlihat seperti pecah atau membentuk gumpalan-gumpalan.

\section{$\underline{\text { Uji Berat Jenis }}$}

Uji berat jenis dilakukan untuk mengetahui berat jenis susu. Tujuan utama dari mengetahui berat jenis susu yaitu untuk mendeteksi kandungan susu tersebut telah mengalami perubahan atau tidak. Menurut Codex dalam Faghih et al., (2011) berat jenis susu segar adalah $1.028 \mathrm{~g} / \mathrm{ml}$. Berat jenis susu harus ditetapkan 3 jam setelah air susu diperah. Penetapan lebih awal akan menunjukkan hasil berat jenis yang lebih kecil. Hal ini disebabkan oleh 3/4 perubahan kondisi lemak dan 3/4 adanya gas yang timbul di dalam air susu. Hasil pengujian sampel dapat dilihat pada Tabel 5. 
Tabel 4. Hasil uji alkohol masing-masing sampel susu

\begin{tabular}{|c|c|c|c|c|c|}
\hline No. & Sampel & $\begin{array}{c}\text { Positif } \\
\text { (Ada } \\
\text { Gumpalan) }\end{array}$ & $\begin{array}{c}\text { Negatif } \\
\text { (Tidak } \\
\text { Gumpalan) }\end{array}$ & Ada & Keterangan \\
\hline 1 & $\mathrm{~A} 1$ & & v & & $\begin{array}{l}\text { Sesuai dengan persyaratan kualitas } \\
\text { susu menurut SNI }\end{array}$ \\
\hline 2 & $\mathrm{~A} 2$ & & v & & $\begin{array}{l}\text { Sesuai dengan persyaratan kualitas } \\
\text { susu menurut SNI }\end{array}$ \\
\hline 3 & A3 & & v & & $\begin{array}{l}\text { Sesuai dengan persyaratan kualitas } \\
\text { susu menurut SNI }\end{array}$ \\
\hline 4 & B1 & & v & & $\begin{array}{l}\text { Sesuai dengan persyaratan kualitas } \\
\text { susu menurut SNI }\end{array}$ \\
\hline 5 & B2 & & v & & $\begin{array}{l}\text { Sesuai dengan persyaratan kualitas } \\
\text { susu menurut SNI }\end{array}$ \\
\hline 6 & B3 & & $\checkmark$ & & $\begin{array}{l}\text { Sesuai dengan persyaratan kualitas } \\
\text { susu menurut SNI }\end{array}$ \\
\hline
\end{tabular}

Tabel 5. Hasil uji berat jenis masing-masing sampel susu

\begin{tabular}{llll}
\hline No. & Sampel & Berat Jenis & \multicolumn{1}{c}{ Keterangan } \\
\hline 1 & A1 & 1,0290 & Berat jenis mendekati berat jenis susu menurut codex yaitu 1.028 \\
\hline 2 & A2 & 1,0289 & Berat jenis mendekati berat jenis susu menurut codex yaitu 1.028 \\
\hline 3 & A3 & 1,0289 & Berat jenis mendekati berat jenis susu menurut codex yaitu 1.028 \\
\hline 4 & B1 & 1,0340 & Berat jenis mendekati berat jenis susu menurut codex yaitu 1.028 \\
\hline 5 & B2 & 1,0340 & Berat jenis mendekati berat jenis susu menurut codex yaitu 1.028 \\
\hline 6 & B3 & 1,0342 & Berat jenis mendekati berat jenis susu menurut codex yaitu 1.028 \\
\hline
\end{tabular}

Berdasarkan Tabel 5. di atas, dapat diketahui bahwa apabila dibandingkan dengan berat jenis menurut Codex yaitu 1.028 maka dapat dinyatakan bahwa berat jenis sampel susu dari industri susu A dan industri susu B mendekati berat jenis susu yang normal menurut Codex.

\section{Hasil pengujian kualitas kimia susu}

Tujuan dilakukannya uji kualitas kimia yaitu untuk mengetahui sifat-sifat kimia susu yang terdiri dari $\mathrm{pH}$ atau derajat keasaman dan kandungan lemak susu sudah sesuai dengan persyaratan yang telah ditetapkan oleh SNI atau belum sehingga dapat diketahui susu tersebut layak atau tidak layak untuk dikonsumsi. Pengujian kualitas kimia susu yang dilakukan pada penelitian ini meliputi uji pH dan uji kadar lemak. Pada masing- masing pengujian tersebut diperoleh data kualitas kimia susu sebagai berikut.

$\underline{\mathrm{Uji}} \mathrm{pH}$

Uji pH dilakukan untuk mengetahui $\mathrm{pH}$ susu. Tujuan utama dari mengetahui $\mathrm{pH}$ susu yaitu untuk mendeteksi susu tersebut telah mengalami perusakan atau penurunan kualitas atau tidak. Perusakan dan penurunan kualitas susu yang ditandai oleh penurunan atau kenaikan $\mathrm{pH}$ susu dari $\mathrm{pH}$ susu normal dapat terjadi dari hasil aktivitas mikroorganisme maupun pengaruh dari lingkungan sekitar. Menurut SNI pH susu segar adalah 6.5-6.7. Hasil pengujian sampel dapat dilihat pada Tabel 6.

Berdasarkan Tabel 6, dapat diketahui bahwa baik sampel susu dari industri susu A maupun sampel susu dari industri susu $\mathrm{B}$ menunjukkan nilai $\mathrm{pH}$ yang sesuai dengan persyaratan $\mathrm{pH}$ susu menurut SNI yaitu antara 6.5-6.7. Apabila dibandingkan dengan $\mathrm{pH}$ normal susu menurut SNI yang berkisar 6.5-6.7 maka dapat dinyatakan bahwa nilai pH dari masing-masing sampel susu tersebut sudah sesuai dengan nilai pH susu normal menurut SNI sehingga sampel susu dari kedua industri susu dapt dinyatakan aman untuk dikonsumsi. Nilai pH susu yang lebih tinggi dari 6.7 dapat disebabkan oleh susu berasal dari ambing yang terkena mastitis sedangkan $\mathrm{pH}$ susu yang lebih rendah dari 6.5 disebabkan oleh adanya kolostrum atau adanya pemburukkan oleh bakteri (Nikoyeh et al., 2011). 
Tabel 6. Hasil uji pH masing-masing sampel susu

\begin{tabular}{clll}
\hline No. & Sampel & $\mathrm{pH}$ & \multicolumn{1}{c}{ Keterangan } \\
\hline 1 & A1 & 6.6 & $\begin{array}{l}\mathrm{pH} \text { sesuai dengan persyaratan } \mathrm{pH} \text { susu menurut SNI yaitu 6.5- } \\
6.7\end{array}$ \\
\hline 2 & $\mathrm{~A} 2$ & 6.5 & $\begin{array}{l}\mathrm{pH} \text { sesuai dengan persyaratan } \mathrm{pH} \text { susu menurut SNI yaitu 6.5- } \\
6.7\end{array}$ \\
\hline 3 & A3 & 6.6 & $\begin{array}{l}\mathrm{pH} \text { sesuai dengan persyaratan } \mathrm{pH} \text { susu menurut SNI yaitu 6.5- } \\
6.7\end{array}$ \\
\hline 4 & B1 & 6.5 & $\begin{array}{l}\mathrm{pH} \text { sesuai dengan persyaratan } \mathrm{pH} \text { susu menurut SNI yaitu 6.5- } \\
6.7\end{array}$ \\
\hline 5 & B2 & 6.5 & $\begin{array}{l}\mathrm{pH} \text { sesuai dengan persyaratan } \mathrm{pH} \text { susu menurut SNI yaitu 6.5- } \\
6.7\end{array}$ \\
\hline 6 & B3 & 6.6 & $\begin{array}{l}\mathrm{pH} \text { sesuai dengan persyaratan } \mathrm{pH} \text { susu menurut SNI yaitu 6.5- } \\
6.7\end{array}$ \\
\hline
\end{tabular}

Uji Kadar Lemak

Uji kadar lemak susu dilakukan untuk mengetahui kandungan kadar lemak susu. Kadar lemak susu pada tiap sapi sebenarnya berbeda-beda tergantung pada jenis makanan yang dikonsumsi, tetapi normalnya susu segar memiliki kadar lemak sebesar 3.65\%. Hasil pengujian sampel dapat dilihat pada Tabel 7.

Tabel 7. Hasil uji kadar lemak masing-masing sampel susu

\begin{tabular}{lll}
\hline No. & Sampel & Kadar Lemak Susu (\%) \\
\hline 1 & A1 & 3.65 \\
\hline 2 & A2 & 3.65 \\
\hline 3 & A3 & 3.64 \\
\hline 4 & B1 & 3.60 \\
\hline 5 & B2 & 3.61 \\
\hline 6 & B3 & 3.61 \\
\hline
\end{tabular}

Berdasarkan Tabel 7 di atas, dapat diketahui bahwa sampel susu dari industri susu A dan sampel susu dari industri susu B menunjukkan nilai kadar lemak yang bervariasi. Menurut Margolish et al., (2011) kandungan lemak susu dipengaruhi oleh jenis pakan sehingga uji kadar lemak ini tidak dapat digunakan untuk menentukan kualitas susu secara universal. Pakan yang terlalu banyak konsentrat akan menyebabkan kadar lemak susu rendah sedangkan pakan susu yang berasal dari rumputrumputan akan meningkatkan kandungan lemak susu, khususnya kandungan asam oleat dan asam butirat.

\section{Hasil Validasi Buku Non-Teks}

Hasil penelitian tentang Kualitas Fisika Kimia dan Bakteriologis Susu Sapi selanjutnya dimanfaatkan dalam penyusunan buku non-teks yang berjudul "Sudah Amankah Susu yang Anda Minum Hari Ini!?". Produk buku tersebut merupakan buku pengayaan pengetahuan yang dapat digunakan oleh masyarakat luas karena buku tersebut tidak diterbitkan untuk jenjang pendidikan dan kelas tertentu. Uji validasi buku nonteks dilakukan oleh 3 orang validator yang terdiri dari 1 orang ahli media, dan 2 orang ahli materi. Validasi buku non-teks mengacu pada Kriteria Mutu (Standar) Buku NonTeks yang ditentukan oleh Pusat Kurikulum dan Perbukuan yang terdiri atas kelayakan isi atau materi, kelayakan penyajian, kelayakan bahasa, kelayakan kegrafikaan, dan komponen tambahan lainnya. Adapun hasil dari uji validasi buku non-teks yang sudah dilakukan secara rinci terdapat pada Tabel 8. 
Tabel 8. Hasil Uji Validasi Buku Non-Teks

\begin{tabular}{lccl}
\hline Validator & Total Skor & Nilai Validasi & Kriteria \\
\hline Validator 1 (ahli media) & 78 & $92.86 \%$ & Sangat Layak \\
\hline Validator 2 (ahli materi) & 81 & $96.43 \%$ & Sangat Layak \\
\hline Validator 3 (ahli materi) & 80 & $95.24 \%$ & Sangat Layak \\
\hline \multicolumn{1}{c}{ Rata-Rata } & $\mathbf{7 9 . 6 7}$ & $\mathbf{9 4 . 8 4 \%}$ & Sangat Layak \\
\hline
\end{tabular}

Berdasarkan hasil uji validasi buku non-teks pada Tabel 8 diketahui bahwa total skor tertinggi diperoleh dari validator kedua yaitu sebesar 81 dengan nilai validasi sebesar $96.43 \%$ sedangkan ratarata skor terendah diperoleh dari validator pertama yaitu sebesar 78 dengan nilai validasi $92.86 \%$. Pada hasil uji validasi dari ketiga validator tersebut diperoleh rata-rata skor sebesar 79.67 dengan prosentase rata-rata nilai validasi sebesar $94.84 \%$ sehingga dapat dinyatakan bahwa buku non-teks yang telah diuji validasi tersebut sangat valid untuk digunakan sebagai buku non-teks karena menurut Suparno (2011) buku non-teks dikatakan sangat valid dan siap dimanfaatkan di lapangan sebenarnya apabila memiliki nilai antara $81.1-100 \%$.

\section{KESIMPULAN DAN SARAN}

\section{Kesimpulan}

Pengujian kualitas fisika kimia sampel susu dari industri A dan B menunjukkan hasil yang sesuai dengan persyaratan susu yang baik sesuai dengan persyaratan sifat fisika dan kimia susu yang baik sehingga susu dari industri susu $A$ dan industri susu B layak untuk dikonsumsi. Hasil tersebut juga didukung oleh hasil sampel hapusan tangan pemerah dari industri susu $A$ dan industri susu $B$ yang menunjukkan hasil negatif terhadap pengujian ada tidaknya bakteri Escherichia coli pada tangan pemerah. Kemudian buku nonteks yang dikembangkan dari hasil penelitian dengan judul "Sudah Amankah Susu yang Anda Minum Hari Ini!?" dinyatakan sangat layak untuk digunakan sebagai buku non-teks jenis pengayaan pengetahuan karena prosentase rata-rata nilai validasi yang diperoleh dari ketiga validator sebesar $94.84 \%$.

\section{Saran}

Pengembangan buku non-teks sangat perlu dilakukan pada setiap hasil penelitian ilmiah yang sudah dilakukan agar hasil- hasil penelitian tersebut dapat diketahui oleh masyarakat luas dan menjadi sumber informasi yang akurat dan terpercaya yang kebermanfaaatannya dapat dirasakan oleh masyarakat luas secara langsung.

\section{DAFTAR RUJUKAN}

Abargouei AS, Janghorbani M, Salehi-Marzijarani M, Esmaillzadeh A. (2012). Effect of dairy consumption on weight and body composition in adults: a systematic review and meta-analysis of randomized controlled clinical trials. Int J Obes (Lond) 36:1485-93.

Abreu S, Santos R, Moreira C, Vale S, Santos PC, Soares-Miranda L, Marques AI, Mota J, Moreira P. (2012). Association between dairy product intake and abdominal obesity in Azorean adolescents. Eur J Clin Nutr 66:830-5.

Abreu S, Santos R, Moreira C, Santos PC, Vale S, Soares-Miranda L, Mota J, Moreira P. (2012). Milk intake is inversely related to body mass index and body fat in girls. Eur J Pediatr 171:1467-74.

Arriola L, Balkau B, Barricarte A, Boeing H, Bueno-de-Mesquita HB. (2012) The amount and type of dairy product intake and incident type 2 diabetes: results from the EPIC-Interact study. Am J Clin Nutr 96: 382-90.

Chen M, Pan A, Malik VS, Hu FB. (2012). Effects of dairy intake on body weight and fat: a metaanalysis of randomized controlled trials. Am J Clin Nutr 96:735-47.

Faghih S, Abadi AR, Hedayati M, Kimiagar SM. (2011). Comparison of the effects of cows' milk, fortified soy milk, and calcium supplement on weight and fat loss in premenopausal overweight and obese women. Nutr Metab Cardiovasc Dis 21:499-503. 
Jushadi Arman Saz, Fadhila, Nurhayati, Ahmad Yani. (2015). Pengembangan Media Presentasi Interaktif Semi Laboratorium Virtual Pada Pokok Bahasan Listrik Dinamis. Jurnal Saintifik 1: 2633

Josse AR, Atkinson SA, Tarnopolsky MA, Phillips SM. (2011). Increased consumption of dairy foods and protein during diet- and exerciseinduced weight loss promotes fat mass loss and lean mass gain in overweight and obese premenopausal women. J Nutr 141: 1626-34.

Malik VS, Sun Q, van Dam RM, Rimm EB, Willett WC, Rosner B, Hu FB. (2011). Adolescent dairy product consumption and risk of type 2 diabetes in middle-aged women. Am J Clin Nutr 94:854-61.

Margolis KL, WeiF, deBoerIH, HowardBV, LiuS, MansonJE, Mossavar Rahmani Y, Phillips LS, Shikany JM, Tinker LF. (2011). A diet high in low-fat dairy products lowers diabetes risk in postmenopausal women. J Nutr 141:1969-74.

Mozaffarian D, Cao H, King IB, Lemaitre RN, Song X, Siscovick DS, Hotamisligil GS. (2011). Transpalmitoleic acid, metabolic risk factors, and new-onset diabetes in U.S. adults: a cohort study. Ann Intern Med 153:790-9.

Mozaffarian D, de Oliveira Otto MC, Lemaitre RN, Fretts AM, Hotamisligil G, Tsai MY, Siscovick DS, Nettleton JA. (2013). Trans-palmitoleic acid, other dairy fat biomarkers, and incident diabetes: the MultiEthnic Study of Atherosclerosis (MESA). Am J Clin Nutr 97: 854-61.

Nikooyeh B, Neyestani TR, Farvid M, Alavi-Majd H, Houshiarrad A, Kalayi A, Shariatzadeh N, Gharavi A, Heravifard S, Tayebinejad N. (2011). Daily consumption of vitamin D- or vitamin D + calciumfortified yogurt drink improved glycemic control in patients with type 2 diabetes: a randomized clinical trial. Am J Clin Nutr 93:764-71.

Priansa, J, D. (2015). Manajemen Peserta Didik dan Model Pembelajaran Cerdas,Kreatif, dan Inovatif. Bandung: Alfabeta.

Rostina, Ahmad Yani. (2016). Pengembangan Perangkat Pembelajaran Fisika Berbasis Penemuan Terbimbing Materi Gerak untuk Peserta Didik Kelas VII SMPN 1 Bulukumba. Jurnal Sains dan Pendidikan Fisika 12 (3): 254-269

Sanders TA. (2012). Role of dairy foods in weight management. Am J Clin Nutr 96:687-8.

Sousa GT, Lira FS, Rosa JC, de Oliveira EP, Oyama LM, Santos RV, Pimentel GD. (2012). Dietary whey protein lessens several risk factors for metabolic diseases: a review. Lipids Health Dis 11:67.

Struijk EA, Heraclides A, Witte DR, Soedamah-Muthu SS, Geleijnse JM, Toft U, Lau CJ. (2013). Dairy product intake in relation to glucose regulation indices and risk of type 2 diabetes. Nutr Metab Cardiovasc Dis 23:822-8.

Tong X, Dong JY, Wu ZW, Li W, Qin LQ. (2011). Dairy consumption and risk of type 2 diabetes mellitus: a meta-analysis of cohort studies. Eur J Clin Nutr 65:1027-31. 